\title{
The Flow of Garbage: From Laurence to Phong
}

\author{
Nicholas O. Pagan
}

The Oxford English Dictionary gives as its first definition of "garbage," "the offal of an animal used for food, especially the entrails. Rarely the entrails of a man." ${ }^{\prime 1}$ After being used to refer to "discarded parts of butchered fowls" or "food wastes as from a kitchen," garbage later came to designate "any matter that is no longer wanted or needed," or "anything that is completely worthless . . . or vile." 2 The word "garbage" is preferred in this essay to "trash" because "garbage," though sometimes used as an adjective ("the garbage chute"), is almost always employed as a noun and never a verb. You can lose your temper and "trash" someone else's or even your own apartment, but you cannot "garbage" an apartment. Thus the word "garbage," invariably a noun, is good at retaining its connection to "thingness" as in the above definitions - whether it be the thingness of food waste, superfluous matter or items deemed useless or extremely unpleasant. ${ }^{3}$

Whereas certain groups of people are sometimes referred to as "trash," especially some poor Southerners in the United States disparagingly designated "white trash," it is not so common to label people "garbage.", One person who has nothing but contempt for another may label him "garbage," especially if that other is connected in some way to the physical reality of garbage - he works with it, lives in close proximity to it, smells of it, and so on. A literary work may be more likely to be dismissed as "trash" rather than "garbage" —as in the recent blogs "Fifty Shades of Grey-Literature or Trash?" and "Stephen King: Trash or Literature?" but here, rather than using words like "trash" or "garbage" to raise question marks about whether certain forms of writing are worthy of the label "literature," I prefer to 
focus on the way in which literature is able to exemplify the multifarious possibilities of "trash" or "garbage" as a theme.

To concentrate on the literature/garbage nexus is to write in the wake of the work in particular of Walter Moser who in essays like "Garbage and Recycling: From Literary Theme to Mode of Production," has admirably sketched some of the history of literature's recourse to garbage from Louis-Sébastien Mercier in 18th century France up to and including contemporary writers like the Puerto-Rican Fernandro Contrera Castro, the Italian Paolo Teobaldi and the Jewish-American Paul Auster. Moser astutely reconceptualizes garbage in relation to categories that include "psychoanalytic dimensions" related to anality and ideas of expulsion, retention, and cleanliness; "economic, affective and aesthetic values"; and "memory and archaeological knowledge of the past." He also provides a useful grid adaptable for future work on the literary theme of garbage by suggesting subthemes such as (i) the gatherer, who also cusomtarily lives off garbage (the common denominator in many liteary works); (ii) the gatherer who is also a recycler; (iii) the one who lives in a garbage dump; (iv) the one who becomes garbage; and (v) the one whose attitude toward garbage is philosophical.

One way in which my work differs from Moser's is that I try to make more use of the comparativist dimensions. Apart from brief considerations of the Chinese writer Cheng's “The Chess King," Moser confines his examples to the Western tradition. Here, by focusing on literary representations of garbage and its ramifications in relation to how people in diverse cultures think and behave, I attempt to draw out the East/West distinction. Toward the end of the essay I suggest the term "garbagescape" to capture the idea that the spread of garbage is an integral part of globalization, and I try to show how although their canvases could be smaller than those of their North American counterpart writers from the East, they could also be very effective at highlighting garbage as a global issue. They also encourage us to question 
whether garbage is always a "bad" thing, as "vile" and "useless" as traditional dictionary definitions tend to suggest.

From North America I pass over Barthelme's Snow White (treated in detail by Moser) and concentrate on Margaret Lawrence's The Diviners (1974) before looking briefly at the representations of garbage in Don DeLillo's Underworld (1997). Later as representative of the Far East I focus attention on the Vietnamese writer The Phong's "The Rubbish Tip Outside the City" (1970). While it is relatively easy to find basic biographical details about North American authors like DeLillo, I have been unable to unearth any information about the Vietnamese writer The Phong except that he wrote The Rubbish Tip Outside the City and Other Stories in Saigon, South Vietnam between 1960 and 1963. ${ }^{5}$

Making an appearance near the beginning of Laurence's The Diviners the character most associated with garbage is given a name with religious connotations, "Christie." Christlike behavior may be reflected in his turning the proverbial other cheek when riding in his wagon with Morag, he becomes the object of the young peoples' ridicule as the boys sing,

Christie Logan's the Scavenger Man

—Gets his food from the garbage can! (Laurence, 1974: 31)

Showing no signs of feeling humiliated, Christie's response is to laugh, and because it is obvious that there will be no counter-offensive, the boys retreat. Seated beside her stepfather young Morag, on the other hand, feels a deep sense of shame—she cries "with her head down, so as not to be seen", both because another chant is directed at her, "Mo-rag! Morag!/ Gets her clothes from an ol' flour bag," and because one of the adults who is bringing her up has retreated into what she sees as cowardly laughter.

Referring to the occupants of many of the houses along the way, Christie tries to explain:

“. . . you can see from what their kids say, what they're saying. Some of them because I take out their muck, they think I'm muck. Well, I am muck, and so are they. Not a father's son, not a man born of woman, who is not 
muck in some part of his immortal soul, That's what they don't know, the poor sods. When I carry away their refuse, I'm carrying off part of them, do you see?" (ibid: 32)

Christie can be seen to be bridging three of the categories listed by Walter Moses-he is garbage collector; he is garbage ("muck") at least in the eyes of others; and his attitude toward garbage is philosophical — especially as he suggests a correlation between a person's garbage and his or her "being." "By their garbage shall ye know them," continues Christie, and he playfully fuses the name of Christ with his own name to form an adverb, parodying Biblical pronouncements like "By their fruit you will recognize them" (Mat. 7:16) when he says, “... by their bloody goddamn fucking garbage shall ye christly well know them" (Laurence, 1974: 33; emphasis added). Undercut by his recourse to "bad" language Christie also endows himself with a Christ-like purity in his not wanting to judge other people- "I see what they throw out [copious bottles of alcohol, family albums, condoms. . .] and I don't care a shit, but they think I do, so that's why they cannot look at me" (ibid). The shame is theirs, not Christie's, not Christ's. They are the ones who wrapped the rye bottles with newspaper pages to disguise their extensive drinking. They are the ones who conceal their "safes" in the garbage because they fear that if they flush them down the toilet they will be discovered by a plumber unblocking the pipes.

“They think muck's dirty," Christie continues, "It's no more dirty than what's in their heads. Or mine. It's christly clean compared to some things" (33). There is a hint here of what Walter Moser refers to as the psychoanalytic dimension of garbage as the problems seem to be all in the mind as Christie, not afraid to free associate, has lapsed (from Morag's point of view) into one of his "spiels" (32). Morag, however, is hardly an appropriate person to act as therapist (if Christie aims at a "talking cure"). She hears Christie's words but can make no sense of them because she is too consumed by her own humiliation as the boys' songs were 
directed not only at Christie but also at her, and she is far from being able to laugh at the boys, the songs, or herself.

Christie's nickname as heard in the boys' song is "the Scavenger Man" or just "Scavenger Man" and Christie transports the garbage to "The Nuisance Grounds" which surely owes its name to the idea that for most "good" people, garbage indeed is a nuisance; it gets in the way; it is better hidden away somewhere-“Out of Sight, Out of Mind." For Christie though as he tries to explain to young Morag, garbage means work (this is during the Depression when millions are unemployed), and it means warmth (the family is better placed than any other to get their wood from the Nuisance Grounds). Christie does not mind the families in the houses up on the hill looking down at him:

Let them I say unto you, Morag, girl, I open my shirt to the cold winds of their voices, yea, and to the ice of their everlasting eyes. They don't touch me, Morag. For my kin and clan are as good as theirs any day of the week, any week of the month, any month of the year, any year of the century, and any century of all time. (38-39)

Christie Logan in The Diviners stands up against a long-lasting and continuing (and as we will see quite universal) prejudice against all who work or live with garbage, a smug and insidious contempt for homo detritus. Christie is also one person in a line of loquacious garbage collectors. On another occasion sitting on the wagon with Christie and her friend Skinner Tonnerre, Morag thinks, "Why can't he shut up? Why can't he just shut up? Crazy Christie. But he can't shut up. He can't at times ..." (62). Christie can't keep quiet because he has a gift, "the gift of garbage-telling" (61), and if you have a gift you may as well use it.

In addition to obvious benefits like old abandoned wooden furniture providing wood for the fire to keep the family warm, garbage can provide people with an exponential number of variegated stories. There may be a limited number of ways of putting something into the garbage, but there are an infinite number of ways of taking it out. Taking it out is Christie's profession—not just taking it out, but putting it out there, talking garbage. 
While garbage is only a theme in the first section of The Diviners, the "Nuisance Grounds" section, garbage runs as an indefatigable undercurrent throughout the many pages of DeLillo's Underworld, being an integral part not just of the protagonist Nick Shay's jobhe is a waste management consultant — but also Nick's and a number of other key characters' view of the world. Thus when Nick and his wife went shopping they saw "products as garbage even when they sat gleaming on the shelves, yet unbought. . ." "First we saw the garbage," explains Nick, "then we saw the product as food or lightbulbs or dandruff shampoo" (121). As the future collapses into the present, the idea that products are fated to become garbage means that "garbage-to-be" becomes synonymous with "garbage-now." Garbage appears to be blessed with a permanence which will always give it the upper hand over non-garbage.

Nick senses this timelessness again when he explores a waste treatment plant in Holland where it is not so much the sight of the steam-filled rows and rows of garbage piled one storey on top of another and on top of another that overwhelms him; it is the stench: "there was a stink in the air that filled my mouth, that felt deep enough to singe my clothes" (104). Sounding like a cross between Dante and some more contemporary sage, Nick concludes this particular reflection on garbage by insisting that we have all undertaken the journey through garbage:

Every bad smell is about us. We make our way through the world and come upon a scene that is medieval-modern, a city of high-rise garbage, the hell reek of every perishable object ever thrown together, and it seems like something we've been carrying all our lives. (194)

This insistence on a connection between bad smells and "us" is reminiscent of Christie's refrain in The Diviners, "By their garbage shall ye know them!" but rather than implying a connection between any given piece of garbage and any individual at any given time, Nick reflects on a primordial link between reeking garbage and all of us, as soon as we come into the world. Thus, pontificating, Nick moves inexorably from the singular "I" as in 
"Why did I think I was born with this experience in my brain" to the plural "we""something we've been carrying all our lives," and he implies that for a human being to be born means to be born into garbage. We are born into garbage just as our parents were born into garbage and our parents' parents and their parents before them, as far back as and even prior to medieval times. To be human is to be enmeshed in garbage. The "high-rise garbage" cannot have sprung up of its own accord. The rows and rows of reeking waste that Nick surveys were not spewed out by nature. Human beings created this garbage, and its smell and our smell, like it or not, are one.

Nick Shay may certainly be thought of as falling into Moser's category: the one whose attitude to garbage is philosophical, but Nick places himself in the company fellow wastemanagement experts who are able to talk garbage with even more eloquence. One day Nick finds himself with Big Sims (a colleague and jogging partner) out in the desert examining a huge landfill in the early evening along with Jesse Detwiler, labeled appropriately "a waste theorist." In the past Detwiler was not above stealing and examining the garbage of famous people. Talking to Nick and Sims, Detwiler suggests that toxic waste will one day become a tourist attraction (286), and he proceeds to ruminate about the enormous power of garbage:

... cities rose on garbage, inch by inch, gaining momentum through the decades as buried debris increased. Garbage ... had its own momentum. . . . It pushed into every space available, dictating construction patterns and altering systems of ritual. And it produced rats and paranoia. People were compelled to develop an organized response. This meant that they had to come up with a resourceful means of disposal and build a social structure to carry it out-workers, managers, haulers, scavengers. Civilization is built, history is driven-(287)

According to Detwiler, and perhaps this gels with Nick's insistence that we are born into garbage, garbage comes first, and civilization follows (288). Detwiler's vision, however, is essentially a Western one, and in particular an American one. When Detwiler goes on to taunt his interlocutors for placing their garbage on "sacred Indian land" Nick and Sims are able to offer no response, but when Detwiler mentions a ship full of waste "cruising the 
oceans of the world to dump some hellish substance" he succeeds in getting his fellow American toxic waste experts' attention with the news that "it's headed back to the U.S." (Ibid) In their work with toxic waste these experts may sometimes venture abroad as Nick did to Holland, but their primary focus is always America. There are distinct suggestions of American insularity in Sims' and Nick's response to Detwiler's passionate monologue ending with the insider knowledge that the toxic waste laden ship is returning to the US because Sims's reaction to Detwiler's new-fangled post-1960s ideas is "What do we know, Nick?" and his suggestion that all they really know about is The Lone Ranger which in America filled the radio airwaves throughout the Forties and Fifties.

Although incorporating a vast array of subject matter from baseball to highway shootings, from marital infidelity to nuclear weapon proliferation, from the Cuban Missile Crisis to Christian mysticism, DeLillo's vast novel Underworld may also be read as a meditation on garbage. In a rare radio interview DeLillo himself points out that one way of thinking about the title, Underworld, is to see it as referring to "the very substantial and dangerous underworld of toxic waste," and he urges fellow or would-be writers "to maintain a certain tacit opposition to . . the whole process of consumer consciousness, of white hot consumption and instantaneous waste" (Interview with Terry Gross, originally broadcast on the radio as part of NPR's series "Fresh Air"). From the first sentence of Underworld in which DeLillo announces a distinctively "American" voice (11), however, there is the suggestion that the concerns of the novel (and the novelist) are going to be predominantly American. The general tendency for the novel to look inward at American society rather than to the outside world beyond America's borders is hinted at by the minor character Sims's decision when he was a young man to go into a career that would be built on landfills in the U.S. while in college as a student of engineering he had dreamed of going to Tunisia to build roads. (283). Similarly, although for his work Nick sometimes has to travel abroad as when he 
goes to Holland, his concerns remain if not entirely American, then at least Western. Thus, when he announces that "Every bad smell is about us," this "us" may include Europeans, people from the West, for none of the peoples of the East are ever mentioned in Underworld except in the context of The Cold War which merely accentuates the East/West divide and makes it even more difficult to think of the "us" as universal.

At first glance the Vietnamese writer The Phong's short story "The Rubbish Tip Outside the City" would seem to be far, far removed from DeLillo's Underworld both in terms of the size of its canvas and the provincialism of its concerns - for instance, the disputes between landlords and tenants about a few simple sheds erected on a piece of land located between paddy fields and textile mills on one side and rubber plantations on the other. Along with the title, the fact that these sheds have been built next to a garbage dump immediately suggests that Phong shares a concern with garbage with the North American writers discussed above. Instead of having one character rhapsodize about garbage like Christie in The Diviners or Jesse Detwiler in Underworld, Phong portrays a whole community living with and utterly dependent on garbage for their livelihood.

In "The Rubbish Tip" the vital economic importance of garbage for many poor families is made very clear by the narrator, himself a tenant sharing one of the sheds with a friend, when he notes at one point that there are sixty families living off the garbage supplied to them by another tenant, a former airman called Tiet (9). Tiet is able to get one thousand piestas from one truck of garbage (9), and he can get more money for fifty abandoned rocket shells than the narrator can get for publishing one of his stories (7). Two and a half rocket shells are valued as the equivalent of what an average family spends each day on dry fish and vegetables (7). It is worth noting that such dry, but for the people concerned absolutely crucial, economic data is not to be found in any of the North American literature considered above. None of the characters who live off garbage in the works by DeLillo (and Auster) 
have, for instance, to weigh off how much they make from garbage against how much they pay for rent in order to see what chance they and their families have of surviving.

Another key difference between Phong's "The Rubbish Tip" and its North American counterparts is that whereas the latter's glance invariably fails to pay much attention to the Other as in the Middle or Far East, "The Rubbish Tip" always seems to have one eye on the Other as the West, especially The United States. Thus, the garbage trucks are sent to the rubbish tip by the Americans, and if the locals want to be the beneficiary of this "American" garbage, then they have to speak American. This is precisely Tiet's advantage. His recourse to the Other's tongue enables him to "do business" with what the locals call "the Yankees" and to thus obtain "“valuable rubbish" (8). One member of Tiet's family starts being referred to as a "cowboy" (13) and eventually the whole community becomes completely dependent on those who Tiet braggingly refers to as his "good Yankee friends" (8). This chronic dependency is expressed most vividly by Tiet's wife when following his arrest she decides that in the absence of garbage she has to prostitute herself. After an all-night liaison with a "foreigner" behind a tomb in "the forest of love," she states quite candidly: "I 'love' the Yankee for money. What's wrong about it?" (16). If the Americans are not offering cash or "good" garbage (meaning that readily convertible into cash) in exchange for sex, then they just sit on the fence or in this case on the truck. After Tiet is carted off to prison as fights break out between rival, impoverished families, "the GI's on the truck looked at the scene, smiling benignly" (16). Is this the placid West's indifference to anything but their own selfinterest?

The narrator poignantly contrasts what he sees as America's successful evolution with his own little community's spectacular failure:

We moved to this place, like the Americans coming to the West in the founding years. Here ended the similarity. They succeeded in making the region prosperous 
and a good place to live in. We can still see the great Western tradition in many good films. As for us, it was not quite the same story and no movies ever recorded what happened to us. (17)

Could an impoverished slice of a Vietnamese community like this be included in the "us" of DeLillo's Underworld? In "The Garbage Tip" eventually the houses of the people who had been living on garbage are flattened by bulldozers. Do the American dumpers of garbage care? Or do the Americans at least as characters in literary fictions written by writers from North America, show any signs of caring about the plight of such people living with garbage on the other side of the globe? Surely, just as DeLillo was very concerned that the language of his novel Underworld be considered "American," the concerns of the characters therein are predominantly American, and for North American fiction in general the garbage or waste issue is above all an American issue.

Cultural anthropologist Arjun Appaduai has described globalization in relation to five dimensions: ethnoscapes, technoscapes, finanscapes, mediascapes, and ideoscapes. All entail "flows": ethnoscapes, for example, involve "flows of immigrants, refugees, exiles, guest workers, and tourists," and technoscapes involve "the spread of elements of the Western enlightenment worldview--namely, images of democracy, freedom, welfare rights, and so forth" (295-310). Surely at least one more dimension could be added to Appauduai's list-"garbagescapes"--to denote the flows of garbage, especially from richer to less well-off countries, the flow of filth, especially from the first to the third world.

While North American authors who turn to the theme of garbage in their fiction often tend to create eccentric, aberrant individuals with idiosyncratic attitudes toward garbage (DeLillo's Jesse Detwiler in Underworld), writers in the Far East like Phong show us how garbage as a global phenomenon can transform peoples' lives. Phong's "The Rubbish Tip Outside the City" is particularly effective in showing how a small Vietnamese village community can become dependent on American garbage/money. Non-Western writers like 
Phong may fall short in terms of producing characters capable of canny philosophical meditation on garbage (characters produced most notably by American writers like DeLillo). For non-Western writers, garbage invariably embodies some ethical significance; it never just is. ${ }^{6}$ Through their work authors from the East like Phong are able to demonstrate with some poignancy how the interdependence of garbage and the way people think and behave has serious global implications.

Ultimately, however, the differences between the Western and non-Western authors' literary treatments of garbage may be less important than the similarities. I have certainly not meant to imply that there are no cross-cultural similarities in literary treatments of garbage from around the world. Literature from both sides of the globe has shown that working with, even living with garbage, human beings can demonstrate great resilience. The most memorable image in Phong's short story may be that of "a dirty-faced, heavy-breasted Cambodian Vietnamese carrying a small baby on the back, poking the rubbish heap." "Her energy amazed me" says the narrator (10). Garbage does not have to be depressing. It can point to the indomitable spirit that certain human beings are able to manifest in circumstances which for many would be simply unbearable. 


\section{Works Cited}

Allison, Dorothy. Trash: Stories. New York: Firebrand, 1988.

Appadurai, Arjun. "Disjuncture and Difference in the Global Cultural Economy." Theory, Culture, and Society 7 (1990): 295-310.

Cheng, Ah. The King of Trees: Three Novellas. The King of Trees, The King of Chess, The

King of Children. Trans. Bonnie S. McDougall. New York: New Directions, 2010.

DeLillo, Don. Underworld. New York: Scribner, 1997.

---. "Don DeLillo \& Terry Gross \& Underworld." YouTube. 17 Feb. 2009. Web. 5 Nov. 2013.

Kennedy, Greg. Ontology of Trash: The Disposable and Its Problematic Nature. Albany, NY: SUNY Press, 2007.

Laurence, Margaret. The Diviners. Toronto: McClelland \& Stewart, 1974.

Moser, Walter. "Garbage and Recycling: From Literary Theme to Mode of Production,"

Other Voices: The ejournal of Cultural Criticism 3:1 (2007). Web. 5. Nov. 2013.

Phong, The. "The Rubbish Tip Outside the City." The Rubbish Tip Outside the City and

Other Stories. 2nd ed. Trans. Dam Xuan Can. Saigon, Vietnam: Dai Nam Van Hien, 1971.

Scanlon, John. On Garbage. London: Reaktion, 2005.

\section{Notes}

${ }^{1}$ As John Scanlon points out, the word "garbage" came into English from Old French during the fifteenth century. (Scanlon, 2005: 15).

${ }^{2}$ These defintions are given at http://www.thefreedictionary.com/garbage.

${ }^{3}$ For an intriguing examination of the relationship between the "thingness" of trash and our "human" way of "being-in-the-world" see Kennedy, An Ontology of Trash, a work that relies extensively on Martin Heidegger and Albert Borgmann. 
${ }^{4}$ For a literary represenation of the white trash stereotype see Dorothy Allison, Trash: Short Stories.

${ }^{5}$ In one of the stories, "My Cradle: A Chinese Family," there is an allusion to The Phong as "a literary misfit" (Phong, 1971: 68).

${ }^{6}$ For an example of garbage that is neither "good" nor "bad" but just is, see the British artist Damien Hurst's exhibit "Waste (Twice), 1994" which consists of two large steel-framed glass showcases full of medical waste. For drawing my attention to this exhibit, I would like to thank art historian Marc Fehlmann. The works may be seen online at http://www.damienhirst.com/waste-twice. 